\title{
Criteria for post-growth residential development: The example of the city of Zurich
}

Olivia Wohlgemuth, Marco Pütz

\section{Introduction}

In most large cities in Switzerland, population and economic growth combined with changed lifestyle habits and a demand for more living space have led to a shortage of land as a resource. Revised spatial planning legislation, which came into force in 2014, puts an end to continued urban sprawl and requires that future development be located in existing building zones (LaRES 2014). The creation of additional housing presents some difficulties as $95 \%$ of the building zones in Zurich have already been developed, which means that the focus is now primarily on densification (Wüest Partner 2018: 73). Numerous innovative housing projects demonstrate how inner urban development can be successfully realised and that densification can create value for the entire population.

Growth independence concepts are attracting increased attention from spatial sciences. The post-growth debate could therefore provide an approach that allows urban development to focus on ensuring future growth is more sustainable, quality-oriented and goes beyond the purely quantitative economic growth paradigm. The strategy for sustainable spatial development in the canton of Zurich (LaRES 2014) and other guiding principles for good building already include requirements for ecological and social housing, so approaches from the post-growth debate are also being addressed. These include, firstly, innovations in building techniques and, secondly, housing concepts that reduce individual land consumption and counter social individualisation through flexible uses and shared areas. 
This paper is based on a Master's thesis that investigated the city of Zurich as a case study, exploring the extent to which post-growth can be a guiding principle for residential development and examining which preconditions are required for post-growth housing (Wohlgemuth 2019). The paper aims to develop criteria for post-growth housing projects. To this end the following sub-questions are analysed:

- What are the criteria for future-oriented residential development and what is required for these criteria to be fulfilled?

- To what extent are existing requirements for sustainable, ecological and social housing already post-growth oriented?

The paper is structured in five sections. Section 2 presents the theoretical and conceptual framework. Subsequently Section 3 gives an overview of the methodological approach. The findings are presented and discussed in Section 4 and Section 5 provides conclusions.

\section{Urban development, housing and post-growth}

The topic of urban housing offers much scope for realising post-growth economies or a post-growth society. It is obvious that urban development, urban planning and an appropriately organised housing industry could make postgrowth housing possible. Thanks to cooperatives or other non-profit developers, housing is traditionally a topic that is very close to post-growth ideas. However, even though numerous current housing projects have a great deal to do with post-growth, the theme has been subject to little conceptual research and is comparatively new. In the volume Housing for degrowth - Principles, models, challenges and opportunities, Nelson and Schneider (2019) provide one of the few up-to-date overviews of the challenges and unfavourable developments that characterise the property industry and discuss how postgrowth approaches could offer a response. However, the volume primarily presents examples from practice, ranging from squats to collective forms of living to architectural innovations. The focus is not on a theoretical-conceptual categorisation.

In order to demonstrate the conceptual relations between housing and post-growth, in the following we first outline the most important challenges 
faced by housing in the future and then formulate three central post-growth approaches for housing/residential development.

\subsection{Challenges for housing in the future}

The challenges for housing in the future that are discussed in the scientific and grey literature generally include both ecological and social aspects. To describe the specific situation in Zurich, in this section we draw primarily on planning documents and literature with a clear link to the city of Zurich:

- Impulse zur Innovation im Wohnungsbau (Impulses for innovation in housing) (Birrer and Glaser 2017)

- Auszeichnung für gute Bauten der Stadt Zürich (Award for good building of the city of Zurich) (Hochbaudepartement Stadt Zürich 2019)

- Leitfaden und Checklisten zur nachhaltigen Arealentwicklung für Städte und Gemeinden (Guidelines and checklists for sustainable site development for cities and municipalities) (Hugentobler and Wiener 2016)

- Langfristige Raumentwicklungsstrategie Kanton Zürich (Long-term spatial development strategies canton of Zurich) (LaRES 2014)

- Leitfaden - Erfolgsfaktoren sozial nachhaltiger Sanierungen und Ersatzneubaten (Guidelines - Success factors of socially sustainable redevelopments and replacement new builds) (Martinovits/Diethelm/Durisch et al. 2015)

- Raumplanungsbericht (Spatial planning report) (Kanton Zürich 2018)

- Akzeptanz städtischer Dichte: Erwartungen und Prioritäten zum Wohnen in der Stadt Zürich (Acceptance of urban density: Expectations and priorities for housing in the city of Zurich) (Zimmerli 2018)

On the basis of the current planning documentation and literature we identified eight challenges for housing in the future:

1. Resource and energy efficiency: Housing projects should be as resource-conserving as possible and consider energies from renewable sources. They should also contribute towards achieving the objectives of a '2000-watt society'. Buildings should retain their value in the long term and have long useful lifetimes, they should thus be as adaptable and flexible as possible. 
2. Green spaces and open spaces: Sufficient green spaces are important for a good urban climate and biodiversity. In addition, high-quality outside spaces are needed where residents can spend quality time. Concepts for sharing, swapping and building communities need suitable settings and spaces that can be collectively used.

3. Planning procedures: Information and transparency are important aspects of planning procedures and increase acceptance of changes. Good dialogue between the authorities, developers and the people affected is also indispensable. Furthermore, the public should participate in planning and thus improve projects.

4. Densification: Inner urban development is an overall objective. A high density of uses and efficient land use are crucial. The densities applied should be specific to the locality and in keeping with the surrounding area. Occupancy densities must be increased so as to keep per capita consumption of residential space to a minimum.

5. Society: Buildings must support the development of socially and functionally mixed neighbourhoods. Furthermore, community life, cohesion and belonging should be strengthened, which leads to lively settlements with collectively used spaces. Buildings must contribute towards a city for all.

6. Housing forms: Buildings must be constructed for flexible use and residential space must offer qualities for various lifestyles. This includes new forms of dwelling and an attractive mix of housing with diverse dwelling typologies. Ground floors should also be diversely utilised.

7. Quality of life and sustainability: Buildings should provide a framework for sustainable ways of life and dwelling. Furthermore, sustainably conceived housing projects can strengthen awareness of sustainability issues. In general, a project should improve the quality of life of residents.

8. Fair prices and affordable rents: Low-cost and affordable housing should always be the objective of residential construction. The post-growth debate proposes the idea that the pursuit of profit and speculation must be renounced. 


\subsection{Post-growth approaches for housing}

In the well-known and seminal works of the post-growth debate, the topics of housing and urban development play a rather minor role. Thus the works of Victor (2008), Latouche (2009) and Jackson (2016), all important in the international debate, focus primarily on critiques of growth and capitalism, providing introductions and overviews. The key publications of the German-language post-growth literature also mainly provide orientation and cover the most important terms, concepts and backgrounds of the interdisciplinary debate (e.g. Seidl/Zahrnt 2010, Paech 2012, Schmelzer/Vetter 2019). These fundamental works and also many other publications, often with an applied approach, mention numerous projects and initiatives that are planned and implemented in cities. However, the link to the city tends to remain implicit. Cities or urban neighbourhoods are usually just locations for, e.g., transition towns or urban gardening initiatives. Urbanity, city milieus and the role of urban development and planning receive very little attention. Xue (2019: $185 \mathrm{f}$.) clarifies that it is necessary to explicitly view the city and post-growth together:

'Degrowth depicts a desirable future society that is ecologically sustainable, enhances quality of life and achieves social justice. This means achieving social welfare and social justice while shrinking our levels of production and consumption due to the existence of ecological limits. Both research and social practices need to bridge the domains of welfare and environmental sustainability. For urban planners, the integration of both domains raises a question: What is required to make a sustainable city socially just, or, to make welfare societies ecologically sustainable in the urban context?'

Post-growth is not yet used as a guiding principle for urban development. It is equally rare for housing and post-growth to be considered together in the literature. When, however, post-growth is discussed as an approach for housing, it is possible to identify three general thematic fields: sufficiency, the good life and housing justice.

Sufficiency: Sufficiency on the individual level means requiring fewer material resources and changing lifestyles and consumption habits. Sufficiency 'aims for people to change their behaviour without compulsion and to limit or replace practices that overuse resources. It strives for the sufficient, 
environmentally friendly consumption of energy and materials through low demand for resource-intensive goods and services' (Stengel 2011: 140). It is important to note here that a sufficiency strategy does not demand that people do without what is necessary but rather assumes that an understanding of what is necessary will lead people to voluntarily do without (Stengel 2011: 140).

Good life: In a broad sense, post-growth is about striving for a good life for all. This is not about understandings of prosperity based on material consumption, but about different understandings that rather 'include the complexity of people as relationship beings, overcome the division between production and reproduction and give more space to needs that are not focused on growth and optimisation - like time prosperity, stable and intensive relationships or meaningfulness' (Schmelzer/Vetter 2019:169).

Housing justice / a right to housing: The current debates on rising property prices and housing shortages trigger questions about who owns the land and how cities should develop in the future (Schulz 2017: 13). In particular, population groups with low incomes find it increasingly difficult to rent housing in cities. Post-growth views housing as a human right and a basic need, which means that a dwelling should be neither a financial investment nor a status symbol (Schneider 2019: 16).

In addition to these three topics there are numerous other post-growth oriented approaches that could play a role in urban development (Schulz 2017: $11 \mathrm{ff}$.): solidarity economies (e.g. neighbourhood shops, swap shops, local currencies), alternative energy concepts (e.g. energy cooperatives operating for the common good), community food production (urban gardening, urban farming), shared offices (e.g. co-working spaces) or shared forms of use (e.g. spaces and infrastructures for the sharing economy). As these approaches are not directly related to housing they are not further pursued here.

\section{Methodology}

Methodologically speaking, this investigation is based on a qualitative, interpretative research design. The data were gathered for three case studies in a total of 17 guided, semi-standardised expert interviews. The interviews 
were transcribed and evaluated using a structured and summarising form of content analysis.

The case studies were selected from housing projects that had won prizes in the 'Competition for good buildings' ('Wettbewerb für gute Bauten') of the city of Zurich. Every five years building projects are chosen and presented with awards by an expert jury consisting of architects, town planners, other specialists and representatives of the city council and administration. These projects act as role models for high-quality building and make an important contribution to the quality of the city of Zurich (Amt für Städtebau Zürich, 2016). As the current competition cycle has not yet been finalised, the last prizes awarded for buildings constructed between 2011 and 2015 were considered as possible case studies. Of these, residential buildings were filtered out and three case studies were chosen, all of which were developed by cooperatives. Overall, three or four people from the board of the cooperatives or the team of architects of each project were interviewed. In addition, the interviews covered a fourth group of experts from consultancy, the urban administration and research. 
Table 1: Overview of case studies / source: Amt für Städtebau Zürich, 2016 and data from the interviews

Grünmatt development

Zurich-Friesenberg
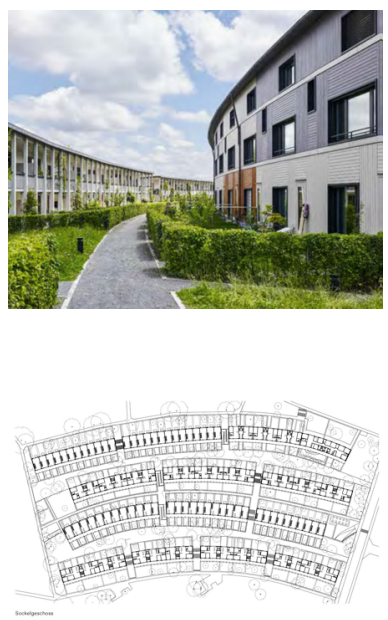

\section{Developer}

Family Home Cooperative Zurich (Familienheim Cenossenschaft Zürich, FGZ)
Hunziker-Areal

Zurich-Oerlikon
Apartment complex Klee

Zurich-Affoltern
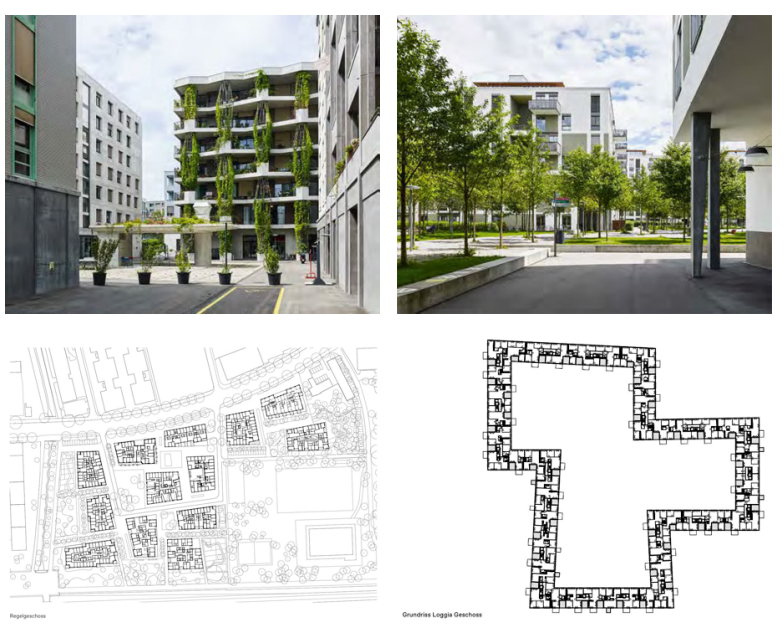

Developer
Building cooperative 'more than
housing' ('mehr als wohnen')

\section{Developer}

Non-profit Building and Rental Cooperative Zurich (Cemeinnützige Bau-und Mietergenossenschaft Zürich) and Building Cooperative Hagenbrünneli (Baugenossenschaft Hagenbrünneli)

\section{Description}

The first replacement new build of the FGZ. A contemporary garden city with low rows of buildings and small, private front gardens was created.

Special feature
A hybrid type of construction was cho-
sen for the new build. Today 490 people
live in Grünmatt, where previously
only 200 people lived in single-family
homes on the same site $(+145 \%)$. Land
consumption is very low, $33 \mathrm{~m}^{2}$ per
person. The previously large private
gardens have given way to a shared
exterior space.

\section{Description}

A car-free development with 13 different residential buildings, high density and a mixed community with strong social cohesion.

\section{Special feature}

The Areal was developed as a jubilee project for the 100th anniversary of the Zurich housing cooperatives and serves as a platform for innovation and learning. The entire Areal is based on a community concept with community rooms and meeting zones. There is a large social mix of inhabitants, reflecting the population of the canton of Zurich.

\section{Description}

Clover-shaped building with a shared park by two cooperatives with different philosophies.

\section{Special feature}

The shape of development provides a large interior courtyard, a highquality and exciting outside space. Architectural interest is provided by the two-storey loggias that are staggered across the floors, while the treetops divide up the façade. This avoids the impression of a six-storey building. 


\section{Results}

Based on current planning documents and literature, Section 2.1 identified eight challenges for housing of the future. These challenges were empirically assessed in the interviews, allowing the requirements for future-oriented housing development to be documented. These requirements have been linked to the post-growth debate and further developed to create a catalogue of criteria (Table 2 ).

Table 2: Catalogue of criteria for post-growth housing / Source: the authors

\begin{tabular}{l} 
Inner urban development \\
Create compact structures \\
\hline Land consumption \\
Limit individual living space \\
\hline User density \\
Strive for high social density \\
High density of interaction \\
Promote high levels of interaction through architectural and organisational measures \\
\hline Mixed land uses \\
Interlink housing, work, retail and recreation to guarantee short distances \\
\hline Diversity \\
Mixed population (lifecycle, lifestyle, income, profession, etc.) \\
\hline
\end{tabular}

Energy sufficiency/ saving resources

Reduce energy consumption and use energy from renewal sources; save resources in construction and utilisation

Green spaces

Extend and protect green spaces for a good microclimate

Appropriation areas

Ensure areas are available that can be freely designed and managed

\section{Participation}

Involve those who are affected in the planning process and in design

\section{Price}

Affordable housing for all population strata 


\section{Inner urban development}

Inner urban development and densification are central elements of spatial development. This enables as many people as possible to live in the city and protects open spaces. The focus here is on building density, i.e. the built fabric, the ratio of the volume of built structures to the surface area of the plot (Wüest Partner 2018: 12). A high building density is equivalent to a high volume of built structures per hectare of the built-up zone.

The dark side of urban sprawl is the loss of natural areas and the increase in traffic. However, densification is also criticised as it is often seen as negative and constricting. Densification therefore needs to always be linked to quality of life - denser is not fundamentally better or worse.

\section{Land consumption}

In order to realise inner urban development and densification, limiting personal living space is crucial. Equally, it is important that the city is accessible as a place of residence for all. Better exploitation of space means there is room for more people in a building or city. This can, first, be achieved by improving the housing, for instance through well-designed floorplans that omit as unnecessary additional square metres of living space that do not create higher quality. A second option is to limit individual living space with occupancy regulations. A third possibility is provided by collectively used areas like guest rooms or offices that can be shared by a number of people if required.

'Housing is something very existential, it needs great care. If you say that you must give up a family dwelling because the children have moved out, I think that's right. You have to do it like that, because otherwise the concept doesn't work, that you say that you do without living space but have instead high-quality and low-priced living space and would like to again make that available then perhaps a generation later to new people. The security of housing, that nobody needs to be afraid of ever being without suitable housing, must be there.' (Interview 15) 


\section{User density}

User density refers to the number of people who spend time in a place and is seen as a prerequisite for people meeting one another (Kretz/Kueng 2016: 55). User density can also be understood as population density or social density and should not be seen as equivalent to built density. A high built density does not in itself mean that more people spend time in a place. If space requirements per person increase and built density remains the same, then the user density sinks. With inner urban development it is important to ensure that the use of land is sufficiently great rather than simply building more concrete.

\section{High density of interaction}

A high user density does not guarantee that people meet and exchange experiences. Loneliness is said to be a problem of modern societies as people feel alone even though urban densities are relatively high. To counter this, housing constructions must allow interaction between residents. Architectural and organisational measures should thus promote rather than hinder community life and exchange between the residents of a building. The design of exterior spaces and the management of semi-public areas has a great influence on whether a building can be collectively used or not. In addition to architectural measures, such as the design of stairways and entrances, shared rooms and infrastructures, e.g. workshops, are important for creating a collective living environment. Among the organisational measures are neighbourhood events or the decentralisation of specific administrative tasks and the organisation of leisure commissions, which include cultural and leisure committees.

To protect the private sphere, it is necessary to find a balance between community and options for withdrawing. An additional difficulty is that such measures are strongly dependent on the residents. Nobody can be forced to communicate with other people. Nonetheless, a framework should be created that promotes and supports such exchanges, should they be desired. 


\section{Mixed land uses}

Ground-floor uses create more lively neighbourhoods with more diverse functions so that the direct surroundings are not just a place of residence but also a place where leisure time can be spent. As well as retail options and leisure facilities in the neighbourhood, co-working spaces can increase the mix of uses. In a 'city of short distances' with a compact structure and mixed land uses, the daily trips to work, the shops and for leisure activities can be undertaken on foot or by bicycle (Beckmann/Gies/Thiemann-Linden et al. 2011: 64). Concentrating retail facilities in shopping centres or pronounced mobility hinder the development of a city of short distances. This leads to an acceptance of longer trips for sport and leisure activities (Beckmann/Gies/ Thiemann-Linden et al. 2011: 61). Nonetheless, mixed uses are necessary to create an attractive residential environment and 'short distances create the possibility of doing without motorised transport so that less resources need to be used. Short distances are also building blocks of a lifestyle and consumption profile that leaves a smaller ecological footprint' (Beckmann/Gies/ Thiemann-Linden et al. 2011: 50).

\section{Diversity}

According to Kretz and Kueng (2016: 50), diversity means 'that different uses, user groups, social milieus and spatial manifestations are present in one space'. In relation to residential development, diversity means that different population groups should be represented in a housing project. A mix of ages, incomes and lifestyles improves the quality of an area and counters segregation. Social mixing of this sort can be achieved in an apartment building by providing different types of dwelling units that attract different people. Such mixing hinders the emergence of disadvantaged neighbourhoods. Furthermore, a high level of diversity can also prevent the development of luxury neighbourhoods for population groups with high incomes. There are, nevertheless, arguments in favour of segregation. The spatial concentration of people in similar situations and with similar interests facilitates the development of specific facilities and infrastructures (Häussermann/Siebel 2001: 73). 


\section{Saving resources and energy sufficiency}

The ecological footprint of the building industry is enormous: worldwide, the industry uses $40 \%$ of global resources (Emprechtinger 2019). In order not to exceed the ecological viability of the planet and due to increasing shortages of building materials like gravel and sand, future building must be as resource efficient as possible. In addition to an economical use of resources for building construction, renewable energies must be used for power in the finished building. No reliance should be placed on technological advances, as while energy efficiency can be continuously improved, sufficiency strategies are nonetheless required:

'(...) If I want to approach something in a sufficient way then first I ask myself whether I need it at all. If I just make it more efficient then I quickly reach the conclusion: now it's more efficient, now I can have more of it. Which need not lead to using less resources at all, but just that you've optimised something.' (Interview 12)

Furthermore, the height, orientation and colour of façades affect the climate. Varied building heights are better for wind effects, and paler colours reflect more light so that the buildings heat up less.

\section{Green spaces}

As well as protecting the landscape, the treatment of green spaces inside the city is crucial. A compromise must be found between green space and inner urban development. Green spaces can make a decisive contribution towards adaptation to climate change and provide protection from overheating. In addition, consideration must be given to the greening of facades, species conservation and biodiversity. Thus native plants should be utilised and not all areas be built with basements so that large trees are able to develop deep roots. Green spaces also increase the attractiveness of the residential environment and housing quality. 


\section{Appropriation areas}

By appropriating open space around dwellings, it becomes possible for people to influence their own living environments. Areas must therefore be planned that have no defined use and that can be managed by the urban residents themselves. Appropriation areas of this sort help a neighbourhood to develop its own distinct character and allow residents to identify with their surroundings. Appropriation is only possible if there is a low level of regulation and a high degree of flexibility in utilisation so that people are as free to act as possible (Kretz/Kueng 2016: 72).

\section{Participation}

The idea of a participative procedure is that development can occur with the public and their thoughts and ideas can be included in the planning process. Furthermore, pursuing collaboration and co-design with the public means that changes are more readily accepted and the quality of the project benefits.

'There is also a certain capital that is brought in. People invest their time, that is their free time, and there are certainly also good and justified idea.' (Interview 16)

It is, however, always important to define precisely who can participate and what the goal of participation is.

\section{Price}

The provision of affordable housing for all strata of the population enables the foundations for a good life to be laid. Housing is a basic need and is existential, which is why urban housing must be affordable for everyone no matter which income bracket they are in.

'I don't like anything about this profit-oriented housing, which isn't sustainable, because people say that they just want to get money out of it now, with overpriced rents.' (Interview 1) 
As there are different income structures there are also different notions of affordability. It is therefore important that in the future all price segments should be represented in the city. This is the only way to enable diversity. Similarly, there should be different price structures on the project level, which can be achieved with different types of dwellings.

\section{Conclusion}

The paper shows that much of the housing that is described as future-oriented or sustainable is already in the spirit of the post-growth debate. Post-growth can be a future-proof guiding principle for residential development in cities and supplement existing principles (inner urban development, quality of life, '2000-watt society'). Post-growth approaches to urban development have to date seldom been analysed in relation to classical housing projects and estate developments, and instead have usually emerged as alternative approaches parallel to the housing market. Although the link to such projects is important, an approach with majority appeal is required, one that is also supported by developers on the classical housing market. The paper demonstrates that post-growth in housing can indeed be generalisable and need not be limited to alternative concepts like transition towns.

Cooperatives play a key role as their form of organisation gives residents a voice and allows their participation in the design of the residential environment. In addition, cooperatives are well known for their experimentation with new ideas and alternative paths. Non-profit developers remove land and real estate from speculation and provide dwellings according to the costrent principle, the housing is affordable for most population strata and is usually cheaper than on the classical housing market. The goal of non-profit developers is to provide environmentally and socially sustainable housing. They are often also pioneers in the transformation of existing forms of housing. Cooperatives are therefore suitable partners for post-growth housing projects.

As well as the non-profit developers as an innovative, post-growth oriented form of organisation, innovations are needed on the technical side and in infrastructure and architecture. With their manifesto for future-proof architecture and structural engineering, architects, engineers and urban planners have demonstrated that they too can act as pioneers of change and 
can assume responsibility for transformation (DAI 2009). Urban development stakeholders involved in housing development have, firstly, responsibility for ensuring that enough dwellings are available for all at a reasonable price. Secondly, housing developers need to ensure that the right housing is planned and built, i.e. dwellings that meet the needs of residents with their different lifestyles and that respond to changes in society.

If post-growth is recognised as a guiding principle for future-oriented housing development, the 'Competition for Good Building' in the city of Zurich could in the future become a competition for post-growth housing. The award-winning projects are already post-growth oriented. A change of terminology for this competition would lead to the post-growth concept becoming better known and could allow the ideas behind it to be more broadly disseminated. Although post-growth is familiar to many academics, a focus on the planning and practice level would further strengthen awareness.

The award-winning projects that were used as a basis for selecting the interview partners, can be viewed as showpieces because they fulfil many of the criteria for post-growth housing. A distinguishing feature of the Hunziker-Areal is that functional neighbourhood infrastructures have been developed in the exterior to create more than just a residential estate. The entire Hunziker-Areal is conceived in terms of community with numerous collective areas and meeting zones. There are over 40 neighbourhood groups active in various fields. Furthermore, the residents of the development reflect the population mix of the canton of Zurich. The whole development experiments with different forms of dwelling and architectural measures. A post-growth perspective suggests, however, that the Hunziker-Areal requires more green spaces. It would be possible to have less sealed surfaces, even though commerce needs a delivery zone for trucks. Green spaces would ensure that the development remains cooler in the summer and would provide inviting places to spend time in, especially as there are very few green spaces in the surrounding area.

The apartment complex Klee in Zurich-Affoltern is an attractive housing development with 340 dwelling units for just under 1000 residents, located on the edge of the city. The social density is high, but the skilful architecture provides many open spaces that can be used by residents. The fact that two cooperatives with different philosophies collaborated on this project made it possible to attract different people. A stricter implementation of all the 
post-growth criteria could achieve a better mix of uses. Although Affoltern is somewhat remote, a focus on public uses in additional spaces on the ground floor would bring life to the area throughout the day.

The Grünmatt project shows how a neighbourhood of single-family homes can be redeveloped to provide attractive dwelling space for more people than before. There are now almost 500 people living in the development where 200 people previously lived. The new build resembles a modern garden city with numerous shared exterior spaces and rooms. Individual consumption of space is thus low, just $33 \mathrm{~m}^{2}$ per person. Another important point is the intelligent heating concept of the Family Home Cooperative (Familienheim Genossenschaft), which recovers waste heat from large companies in the city, stores it in three boreholes and uses it for heating. From a post-growth perspective, efforts should be made to attract a broader mix of residents. The development is very attractive for families and draws many families with small children, but a greater mix of residents would increase quality of life.

In this paper, post-growth has been examined as a guiding principle for housing in the city of Zurich. It would be interesting to apply the same approach to the municipalities of the agglomeration, which is where most land take is currently occurring. This would also allow investigation of whether criteria that are relevant for future-oriented housing projects in the city are also applicable to the municipalities of the agglomeration. As the topic of housing cannot be considered in isolation, future research should also focus on urban development as a whole. This would allow consideration of topics like mobility and the construction of offices and commercial buildings.

\section{Cited literature}

Amt für Städtebau Zürich (2016). „Auszeichnung für gute Bauten“ der Stadt Zürich 2011-2015. Self-published.

Beckmann, K. J., Gies, J., Thiemann-Linden, J., \& Preuss, T. (2011). Leitkonzept - Stadt und Region der kurzen Wege. Gutachten im Kontext der Biodiversitätsstrategie. Umweltbundesamt Verlag. UBA Texte 48/2011.

Birrer, A., \& Glaser, M. (2017). Impulse zur Innovation im Wohnungsbau. Im Fokus, 2017(02). 
DAI - Verband Deutscher Architekten und Ingenieurvereine (2009). Klima-Manifest der Architekten, Ingenieure und Stadtplaner. http://www.klima-manifest.de/praeambel.html.Emprechtinger, F. (2019). LEAD Innovation Management. Bau 2019: Diese 4 Trends bewegen die Baubranche. https://www.lead-innovation.com/blog/bau-2019-trends-baubranche.

Häussermann, H., \& Siebel, W. (2001). Integration und Segregation - Überlegungen zu einer alten Debatte. Deutsche Zeitschrift für Kommunalwissenschaften (DfK), 40(2001-1), 68-79.

Hochbaudepartement Stadt Zürich (2019). „Auszeichnung für gute Bauten“ der Stadt Zürich. www.stadt-zuerich.ch/gute-bauten.

Hugentobler, M., \& Wiener, D. (2016). ANANAS - Leitfaden und Checklisten zur nach haltigen Arealentwicklung für Städte und Gemeinden. vdf.

Jackson, T. (2016). Prosperity without Growth. Foundations for the Economy of Tomorrow. Routledge.

Kanton Zürich (2018). Raumplanungsbericht 2017. RRB Nr. 630/2018, Vorlage 5470. Self-published.

Kretz, S., \& Kueng, L. (2016). Urbane Qualitäten. Ein Handbuch am Beispiel der Metropolitanregion. Hochparterre.

LaRES - Langfristige Raumentwicklungsstrategie Kanton Zürich (2014). Schlussbericht 2014. Self-published.

Latouche, S. (2009). Farewell to growth. Polity Press.

Martinovits, A., Diethelm, E., Durisch, C., Kessler, B., Nigsch, S., \& Noger, P. (2015). Leitfaden - Erfolgsfaktoren sozial nachhaltiger Sanierungen und Ersatzneubaten. Stadtentwicklung Zürich. City of Zürich Press.

Nelson, A., \& Schneider, F. (2019). Housing for degrowth. Principles, models challenges and opportunities. Routledge.

Paech, N. (2012). Befreiung vom Überfluss. Auf dem Weg in die Postwachstumsökonomie. oekom.

Schmelzer, M., \& Vetter, A. (2019). Degrowth/Postwachstum zur Einführung. Junius.

Schneider, F. (2019). Housing for degrowth narratives. In A. Nelson, \& F. Schneider (2019), Housing for degrowth. Principles, models, challenges and opportunities. Routledge, 14-30.

Schulz, C. (2017). Postwachstum in den Raumwissenschaften. Nachrichten $\operatorname{der} A R L, 47(4 / 2017), 11-14$. 
Seidl, I., \& Zahrnt, A. (2010). Postwachstumsgesellschaft. Konzepte für die Zukunft. metropolis.

Stengel, O. (2011). Suffizienz. Die Konsumgesellschaft in der ökologischen Krise. oekom. Wuppertaler Schriften zur Forschung für eine nachhaltige Entwicklung 1.

Victor, P. A. (2008). Managing without growth. Slower by design, not disaster. Edward Elgar Publishing.

Wohlgemuth, O. (2019). Wohnen im Postwachstum. Ein Leitbild für eine zukunftsorientierte Wohnraumentwicklung in der Stadt Zürich. Unpublished Master's thesis.

Wüest Partner (2018). Siedlungsentwicklung nach innen in den Städten. Studie im Auftrag des Schweizerischen Städteverbandes. Self-published.

Xue, J. (2019). Housing for degrowth. Space, planning and distribution. In A. Nelson, \& F. Schneider (2019), Housing for degrowth. Principles, models, challenges and opportunities. Routledge, 185-196.

Zimmerli, J. (2018). Akzeptanz städtischer Dichte: Erwartungen und Prioritäten zum Wohnen in der Stadt Zürich. Vorstellungen von öffentlichem Raum und grossen Überbauungen. Raum + Gesellschaft Press. 


\section{Bastian Lange, Martina Hülz,}

\section{Benedikt Schmid, Christian Schulz (eds.)}

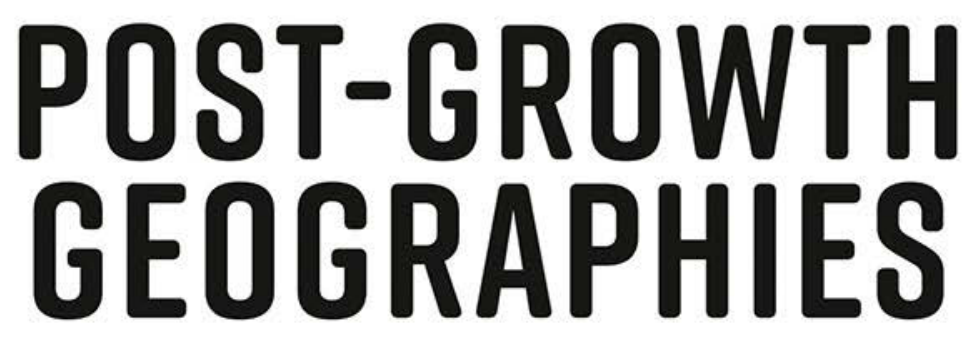

Spatial Relations of Diverse and Alternative Economies

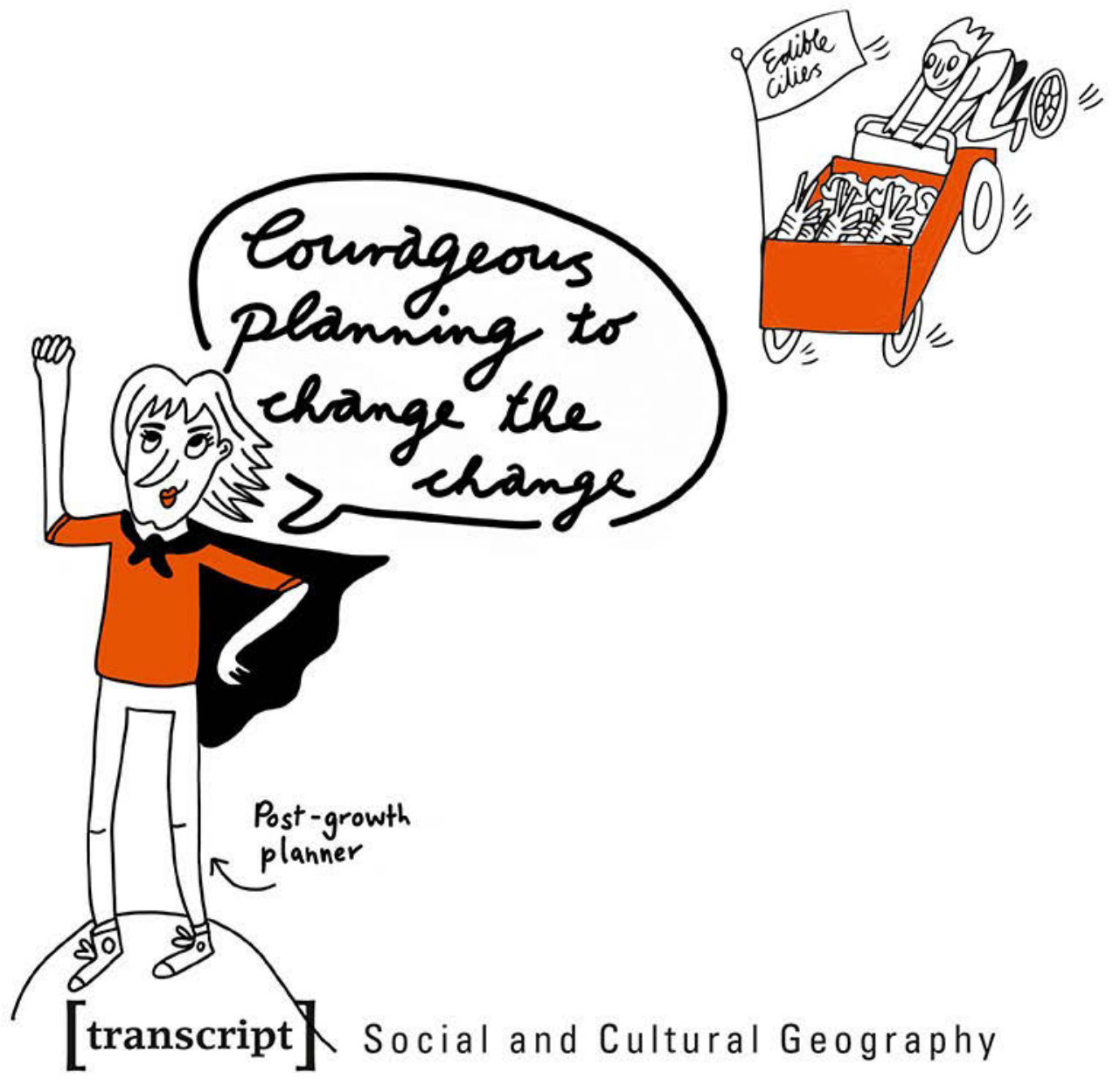


Bastian Lange, Martina Hülz, Benedikt Schmid, Christian Schulz (eds.) Post-Growth Geographies 
With special thanks to Kevin Brendler, Joyce Gosemann and Vanessa Mena Arias (all ARL, Hannover) for the effort and commitment and Katharine Thomas (Kempen) for the translation work.

Bastian Lange studied human geography in Marburg/Lahn and Edmonton. He received his PhD at Johann-Wolfgang-Goethe-Universität Frankfurt am Main in 2006. Since 2017, he has been teaching at the University of Leipzig (habilitation in 2017) . He is conducting research in the field of alternative economies, transition studies, creative placemaking and governance processes. He spearheads Multiplicities, an urban development office that analyzes transition processes, moderates stakeholder processes, and advises municipalities and cities on user-driven local and urban development processes.

Martina Hülz studied geography, sociology and urban planning in Berlin, Bonn and Southampton. She researched and lectured at the universities of Dortmund, Duisburg-Essen and Luxembourg on spatial learning processes, knowledge economics as well as knowledge and technology transfer. After completing her doctorate at the University of Luxembourg, she worked for several years as a project manager in a regional consulting office. Since 2012, she has headed the "Economy and Mobility" department at the Academy for Spatial Research and Planning.

Benedikt Schmid holds a doctorate in geography from the University of Luxembourg and is currently a post-doctoral researcher at the chair Geography of Global Change at the University of Freiburg. His research focusses on the role of community initiatives and social enterprises in the transition towards a post-growth economy.

Christian Schulz studied geography in Saarbrücken/Germany, Québec/Canada und Metz/France. He obtained his PhD from the University of the Saarland (1998), and then worked as a PostDoc/Assistant Professor at the University of Cologne (habilitation in 2004). Since 2006, he has been holding a full professorship for sustainable spatial development at the University of Luxembourg, where he does research primarily on alternative economies and post-growth regimes from an economic geography perspective. 
Bastian Lange, Martina Hülz, Benedikt Schmid, Christian Schulz (eds.)

\section{Post-Growth Geographies}

Spatial Relations of Diverse and Alternative Economies

[transcript] 
We acknowledge financial support by the University of Luxembourg for the English translation of this book, support for the Processing Charge by ARL - Academy for Territorial Development in the Leibniz Association and the Open Access Publication Fund of Leipzig University.

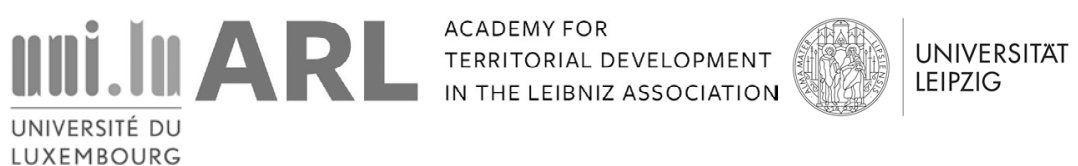

\section{Bibliographic information published by the Deutsche Nationalbibliothek}

The Deutsche Nationalbibliothek lists this publication in the Deutsche Nationalbibliografie; detailed bibliographic data are available in the Internet at http://dnb.d-nb.de

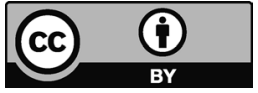

This work is licensed under the Creative Commons Attribution 4.0 (BY) license, which means that the text may be remixed, transformed and built upon and be copied and redistributed in any medium or format even commercially, provided credit is given to the author. For details go to http://creativecommons.org/licenses/by/4.o/

Creative Commons license terms for re-use do not apply to any content (such as graphs, figures, photos, excerpts, etc.) not original to the Open Access publication and further permission may be required from the rights holder. The obligation to research and clear permission lies solely with the party re-using the material.

\section{First published in 2022 by transcript Verlag, Bielefeld \\ () Bastian Lange, Martina Hülz, Benedikt Schmid, Christian Schulz (eds.)}

Cover layout: Maria Arndt, Bielefeld

Cover illustration: Katharina Günther (Thinking Visual), Berlin

Sketchnotes: Viola Schulze Dieckhoff (TU Dortmund University), Dortmund and Joyce Gosemann (ARL), Hannover

Translation: Katharine Thomas, Kempen

Copy-editing: Katharine Thomas, Kempen, Kevin Brendler, Joyce Gosemann and Vanessa

Mena Arias (all ARL), Hannover

Proofread: Bastian Lange (University of Leipzig), Leipzig, Martina Hülz (ARL), Hannover,

Benedikt Schmid (University of Freiburg), Freiburg, Christian Schulz (University of

Luxembourg), Luxembourg

Typeset: Mark-Sebastian Schneider

Printed by Majuskel Medienproduktion $\mathrm{GmbH}$, Wetzlar

Print-ISBN 978-3-8376-5733-3

PDF-ISBN 978-3-8394-5733-7

https://doi.org/10.14361/9783839457337

ISSN of series: $2703-1640$

eISSN of series: $2703-1659$

Printed on permanent acid-free text paper. 